\title{
Ergonomic suitability of educational furniture and possible health implications in a university setting
}

\author{
Nse A Odunaiya' \\ Dolapo D Owonuwa' \\ Oluwafemi O Oguntibeju² \\ 'Department of Physiotherapy, \\ College of Medicine, University of \\ Ibadan, Nigeria; ${ }^{2}$ Department of \\ Biomedical Sciences, Faculty of Health \\ and Wellness Sciences, Cape Peninsula \\ University of Technology, Bellville, \\ South Africa
}

This article was published in the following Dove Press journal:

Advances in Medical Education and Practice

21 January 2014

Number of times this article has been viewed
Abstract: Ergonomically unsuitable school furniture is frequently considered one of the major causes of severe posture problems in adulthood. This study was designed to determine the ergonomic suitability of educational furniture in the lecture theaters at the University of Ibadan to serve as a case study. Sample of convenience was used to select participants for this study. The lecture theaters were selected based on their capacity, design, and dimension. A total of 240 students (120 males and 120 females) participated in this study. The ergonomic suitability of lecture theaters was determined by analyzing the mismatches between student anthropometric dimensions and furniture dimensions, and also by analyzing the design and orientation of the lecture theaters. The data were analyzed using descriptive statistics of mean, standard deviation, range, and median. The results showed that there was a significant difference in height between males and females but no significant difference between other anthropometric variables measured. About $20 \%$ of the participants had a fitting seat height, while seat height was unsuitable for the remaining $80.4 \%$. On the other hand, $23.3 \%$ had a fitting seat depth, while it was unsuitable for $76.7 \%$ of the participants, and $99.6 \%$ of the participants had fitting desk clearance but $0.4 \%$ found it unsuitable. A total of $25.8 \%$ of the participants had a fitting desk height, while $74.2 \%$ of the students found it unsuitable. It was concluded that the furniture in the lecture theaters at the university studied was not ergonomically suitable for the students. Hence it is recommended that further studies, including more universities across a wide spectrum of society, should be performed to determine the effect of furniture on student health, and the need to adopt the use of adjustable furniture in lecture theaters to prevent health hazards that may occur secondary to the use of unsuitable furniture.

Keywords: unsuitability, furniture, possible health hazards, students, university

\section{Introduction}

Furniture plays a vital part in the environment and learning experience/process. It is as important as equipment, buildings, and other learning resources. ${ }^{1}$ Proper implementation of classroom ergonomics is needed for the maintenance of good health, improvement in academic performance, learning, and motivation. ${ }^{1}$

The classroom is similar to other work environments because there is interplay of both "static work" and "force." Static work refers to the musculoskeletal exertion required to maintain or hold a certain position. For example, sitting, and keeping the head and torso upright requires static work; while force refers to the amount of tension generated in the muscles in order to move or keep the body in a particular posture. Hence, the ergonomic requirements for educational chairs are the same as for work chairs. ${ }^{1,2}$ Occhipinti et $\mathrm{al}^{2}$ stated that safety, adaptability, comfort, practicality, durability, and
Correspondence: Oluwafemi

O Oguntibeju Department of Biomedical Sciences, Faculty of Health and Wellness Sciences, Cape Peninsula University of Technology, PO Box 1906, Bellville 7535, South Africa

Tel +27219538495

Fax +27 21 9538490

Email oguntibejuo@cput.ac.za submit your manuscript | www.dovepress.com

Dovepress

http://dx.doi.org// 0.21 47/AMEP.\$38336
Advances in Medical Education and Practice 20I4:5 I-14

(c) (i) (5) 2014 0dunaiya et al. This work is published by Dove Medical Press Limited, and licensed under Creative Commons Attribution - Non Commercial (unported, v3.0) License. The full terms of the License are available at http://creativecommons.org/licenses/by-nc/3.0/. Non-commercial uses of the work are permitted without any further permission from Dove Medical Press Limited, provided the work is properly attributed. Permissions beyond the scope of the License are administered by Dove Medical Press Limited. Intormation on
how to request permission may be found at: http://www.dovepress.com/permissions.php 
suitability are requirements for any work chair. In our opinion, this is also applicable to the university setting.

Improperly designed furniture, ill-fitted to the characteristics of a student can result in faster fatigue, defective posture, and the establishment of pathological states which could affect their performance in focusing in class. ${ }^{3,4}$ A study by Olsen et $\mathrm{al}^{5}$ showed that the ill-fitted design of classroom furniture has contributed to the high incidence of musculoskeletal disorders among school children. The use of ergonomically unsuitable furniture has been shown to lead to musculoskeletal loads and strains, deterioration in health, and a decrease in productivity. ${ }^{6}$ Research in ergonomics has led to heightened interest in the technology of work and furniture design based on the biomechanics of the human body. A few studies have been conducted in some developed and developing countries on the ergonomic suitability of the workplace and the effect it has on the performance of employees. ${ }^{6-8}$ Other studies have assessed the impact of furniture design on the health of its users. ${ }^{9-11}$

A few studies conducted in Nigeria have assessed the design of furniture and anthropometric measures of office and factory workers. ${ }^{12,13}$ However there is a dearth of information on the ergonomic suitability of educational furniture for students, especially in the higher institutions of learning in Nigeria, hence the need to assess the educational furniture of students in a university setting.

\section{Materials and methods Participants}

Participants for this study were students of the University of Ibadan, Ibadan, Nigeria who attended lectures at the selected lecture theaters.

\section{Inclusion criteria}

Only students who gave informed consent participated in this study.

\section{Exclusion criteria}

Students who did not receive lectures in the selected lecture theaters were not considered.

\section{Instruments}

An inextensible tape measure (Butterfly Brand; Shanghai Kearing Stationary Co, Shanghai, People's Republic of China) was used for all anthropometric measurements (overall height, elbow height, shoulder height, upper arm length, knee height, popliteal height, and buttock-popliteal height) of the subjects and the dimension of the furniture (seat height, seat depth, desk height, and desk clearance), except the seat slope and desk slope measurements; measurements were recorded in centimeters.

A plastic universal goniometer consisting of a transparent half circle protractor marked in gradations of 1 degree, calibrated in each direction from 0-180 degrees and with two arms (one movable and the other stationary) attached at a fulcrum located at the center of the protractor, was used to measure the desk slope and seat slope in degrees.

\section{Sample size and sampling technique}

Eleven lecture theaters were selected based on their different furniture design and dimensions, representative of the various forms of furniture that exist in the lecture theaters at the university. The population size was obtained from the number of seats in the largest lecture theater, and sample of convenience was used to select participants. The sample size for each lecture theater was obtained from the equation, ${ }^{14}$

$$
\mathrm{n}=\mathrm{N} /\left(1+\mathrm{N}[\mathrm{e}]^{2}\right)
$$

where $\mathrm{n}$ is sample size to be determined, $\mathrm{N}$ is the population size, and e is the level of precision. The population obtained was from the Faculty of Law lecture theater, which is the largest theater at the University of Ibadan, with 600 seats. The level of precision is $\pm 5 \%$. Therefore, $n=600 /(1+600$ $[0.0025]), n=240$. The sample size proportion for each lecture theater was calculated as,

$\underline{\text { Capacity of lecture theater } \times \text { Sample size }}$

Total capacity of lecture theaters.

The proportionate number of participants from various lecture theaters made up the sample size.

\section{Research design}

The study design was a cross-sectional survey.

\section{Procedure for data collection}

Ethical approval was sought and obtained from the University of Ibadan, University College Hospital Research Ethics Committee before the commencement of the study. Permission to measure the dimensions of the furniture in each lecture theater was granted by the departments concerned. A total of 240 students were proportionately selected from the eleven lecture theaters. The rationale and procedure for this study was explained to the participants, 
and their informed consent was sought and obtained. With reference to Ghazzilla et al, ${ }^{15}$ the following anthropometric measurements were taken over a period of 10 minutes for each participant; their shoes were removed and they wore light clothing:

- Height: the vertical distance from the floor to the top of the participant's head, while standing erect, and looking straight.

- Elbow height: with the participant's elbow flexed 90 degrees, the vertical distance from the bottom of the tip of the elbow to his/her seated surface.

- Shoulder height: the vertical distance from the top of the participant's shoulder at the acromion process to his/her seated surface.

- Upper arm length: the difference between the elbow height and shoulder height.

- Knee height: with the participant's knee flexed 90 degrees in a seated position, the vertical distance from the resting surface of the foot to the top of the knee cap, just above the patella.

- Popliteal height: with the participant sitting and the knee at 90 degrees of flexion, the distance from the foot resting surface to the popliteal space.

- Buttock-popliteal height: with the participant's knee flexed at 90 degrees, the distance/length from the posterior surface of the buttock to the popliteal surface (thigh length).

The following measurements were taken from the furniture in the lecture theaters:

- Seat height: the distance from the floor to the highest point on the front of the seat.

- Seat depth: the distance from the back of the sitting surface of the seat to its front.

- Seat slope: the direction and angle of the slope of the seat's sitting surface.

- Desk height: the distance from the floor to the top of the front edge of the desk.

- Desk clearance: the distance from the floor to the bottom of the front edge of the shelf under the writing surface.

- Desk slope: the angle at which the writing surface of the desk slopes.

Other furniture dimensions, such as desk width (measured as the horizontal distance between the lateral edges of the desk) and desk depth (the distance from the back to the front of the top surface of the desk) were not measured as their suitability criteria were not dependent on anthropometric measurements taken but on the functional requirements that may be derived from them.

\section{Data analysis}

Descriptive statistics of mean, maximum value, minimum value, standard deviation, and percentage were used appropriately to summarize the data collected.

\section{Determination of ergonomic suitability of furniture}

The dimensions of the educational furniture were measured in each lecture theater. The sample size representative of the population of students using the lecture theaters was determined by sample of convenience. The standard body dimensions required were calculated from the mean of the sample size, and this served as the normal value or standard dimension for determining the ergonomic suitability of the furniture in each lecture theater. The standards of measuring suitability were determined by measuring anthropometric mismatches.

Anthropometric mismatches are the number and percentage of the students where the body match or mismatch with the furniture were calculated based on the rules adapted from Parcells et al. ${ }^{16}$ A mismatch is defined as incompatibility between furniture dimensions and the student's body dimension. The mismatch rules are followed in order to determine mismatch between certain body dimensions and their corresponding design parameter as listed below:

- Popliteal height and seat height mismatch: a mismatch is defined when the seat height is either $>95 \%$ or $<88 \%$ of the popliteal height.

- Buttock-popliteal length and seat depth mismatch: a mismatch is defined when the seat depth is either $>95 \%$ or $<80 \%$ of the popliteal height.

- Knee rest height and desk height mismatch: a mismatch is defined as occurring when a desk is $<2 \mathrm{~cm}$ higher than the knee height.

- Elbow rest height and desk height mismatch: according to Parcells et al acceptable desk height is determined by the equation, ${ }^{16}$

$$
\mathrm{hE}=\mathrm{hEv}+\mathrm{U}([1-\cos \theta]+\cos \theta[1-\cos \beta]),
$$

where $\mathrm{hE}$ is the vertical distance from the top of the desk to the student's sitting surface, hS is the shoulder height, hEv is the elbow height, $\mathrm{U}=\mathrm{hS}-\mathrm{hEv}$ is the upper arm length, $\theta$ is shoulder flexion, $\beta$ is shoulder abduction.

According to Chaffin and Anderson, the minimum and maximum acceptable angle of the shoulder during writing is 0-25 degrees for shoulder flexion and 0-20 degrees for 
shoulder abduction. ${ }^{17}$ For flexion angles, the corresponding cosines are 1 ( 0 degrees) and 0.9063 (25 degrees) and for abduction angles, the corresponding cosines are 1(0 degrees) and 0.9397 (20 degrees). Applying the cosines to Equation 3, desk height is determined by,

$$
\text { Minimum desk height }=\text { Seat height }+\mathrm{hE}(2),
$$

where hE $=\mathrm{hEV}+\mathrm{U}[(1-1)+1(1-1)]=\mathrm{hEv}(3)$.

$$
\text { Maximum desk height }=\text { Seat height }+\mathrm{hE}+\mathrm{hS}(4) \text {. }
$$

Based on the above dimensions, it is concluded that a mismatch of elbow-shoulder height and desk height is defined as when the desk was either shorter than the minimum desk height or taller than the maximum desk height. The researchers used the most commonly recommended relationships of mismatch in literature. It is however important to note that the relationships used in this study are not the only ones available. Therefore, other relationships may be used for comparison purposes until there is a consensus and a common standard among researchers.

\section{Results}

\section{Furniture design in relation to seat and writing surface}

In this study, $63.6 \%$ of the selected lecture theaters had cushioned, retractable seats that were fixed to the ground, with a writing surface attached anteriorly. One of the selected lecture theaters had unpadded, wooden seat surfaces, which were fixed and retractable, with a writing surface attached anteriorly. Another selected lecture theater had unpadded wooden seats that were not retractable but were arranged in bench-like rows. One of the lecture theaters had metal seats with a right-sided writing platform. These seats were not attached to one another, and each seat had four leg supports with a foot rest underneath the seat. One of the selected lecture theaters had a metal frame with cushioned seats, and a desk-like horizontal writing surface that was detachable.

\section{Orientation of the educational furniture in the lecture theaters}

At the University of Ibadan, $54.5 \%$ of the selected lecture theaters had a curved-tier-floor orientation, 36.4\% had a horizontal-tier-floor orientation, while the remaining $9.1 \%$ had a level-floor orientation.

\section{Dimensions of the educational furniture}

The eleven lecture theaters used in this study are representative of the different furniture dimensions of the seat and writing surface combinations that exist at the university. The dimensions of the seats and writing surfaces are shown in Table 1.

\section{Anthropometric measurements of students}

Table 2 shows the anthropometric data of the students at the university, classified by sex and lecture theaters. The minimum and maximum values, median, mean, and standard deviation were calculated for all anthropometric variables according to the theaters where the participants received lectures and according to the sex of the participants. An equal number of males and females participated in this study. The maximum and minimum values, mean, and standard deviation were computed for the 240 participants. Measurements of height showed the

\begin{tabular}{|c|c|c|c|c|c|c|}
\hline Venue & $\begin{array}{l}\text { Seat height } \\
(\mathrm{cm})\end{array}$ & $\begin{array}{l}\text { Seat depth } \\
(\mathrm{cm})\end{array}$ & $\begin{array}{l}\text { Seat slope } \\
\text { (degrees) }\end{array}$ & $\begin{array}{l}\text { Desk height } \\
(\mathrm{cm})\end{array}$ & $\begin{array}{l}\text { Desk slope } \\
\text { (degrees) }\end{array}$ & $\begin{array}{l}\text { Desk clearance } \\
(\mathrm{cm})\end{array}$ \\
\hline Faculty of Law lecture theater & 43.0 & 34 & 90 & 71.5 & 90 & 69 \\
\hline Faculty of Social Science theater & 50.5 & 39 & 95 & 74.5 & 90 & 72.5 \\
\hline Chemistry lecture theater & 42.5 & 25.5 & 90 & 79.5 & 90 & 77 \\
\hline Faculty of Science lecture theater & 36.5 & 47.5 & 100 & 70.5 & 90 & 67.5 \\
\hline Anthropology lecture theater & 45 & 40 & 95 & 67.5 & 90 & 66 \\
\hline Statistics lecture theater & 36.5 & 39.5 & 90 & 62 & 90 & 59 \\
\hline Faculty of Agricultural Science lecture theater & 42 & 36.5 & 90 & 62.5 & 90 & 60.5 \\
\hline Physiology lecture theater & 46.5 & 41.5 & 90 & 78.5 & 90 & 76.5 \\
\hline Physiotherapy lecture theater & 40.5 & 38.5 & 95 & 67 & 90 & 65 \\
\hline College auditorium & 35 & 40.5 & 90 & 65 & 90 & 62.5 \\
\hline Paul Hendrickse lecture theater & 32.5 & 39 & 90 & 64.5 & 90 & 60.5 \\
\hline
\end{tabular}

Table I Furniture dimensions of the selected lecture theaters at the University of Ibadan 
Table 2 Anthropometric dimensions of students at the University of Ibadan classified by lecture venue and sex

\begin{tabular}{|c|c|c|c|c|c|c|c|c|c|}
\hline \multirow[t]{2}{*}{ Venue } & \multirow{2}{*}{$\begin{array}{l}\text { Anthropometric } \\
\text { dimension }\end{array}$} & \multicolumn{4}{|l|}{ Male } & \multicolumn{4}{|c|}{ Female } \\
\hline & & $\begin{array}{l}\text { Min } \\
\text { value }\end{array}$ & $\begin{array}{l}\text { Max } \\
\text { value }\end{array}$ & Median & $\begin{array}{l}\text { Mean } \\
\text { (mean士SD) }\end{array}$ & $\begin{array}{l}\text { Min } \\
\text { value }\end{array}$ & $\begin{array}{l}\text { Max } \\
\text { value }\end{array}$ & Median & $\begin{array}{l}\text { Mean } \\
(\text { mean } \pm S D)\end{array}$ \\
\hline Paul Hendrickse & Height & 163.5 & 188.0 & 178.5 & $177.8 \pm 6.8$ & 156.0 & 178.0 & 167.0 & $167.7 \pm 6.3$ \\
\hline lecture theater & Elbow height & 12.5 & 22.0 & 19.8 & $18.8 \pm 2.9$ & 14.0 & 22.5 & 16.5 & $17.0 \pm 2.6$ \\
\hline \multirow[t]{5}{*}{$n=29$} & Shoulder height & 55.5 & 65.0 & 61.0 & $61.4 \pm 2.7$ & 52.0 & 62.5 & 55.5 & $56.6 \pm 2.7$ \\
\hline & Upper arm length & 39.0 & 45.0 & 43.3 & $42.5 \pm 1.9$ & 37.5 & 43.0 & 39.5 & $39.6 \pm 1.5$ \\
\hline & Knee height & 51.5 & 61.5 & 55.0 & $55.6 \pm 3.6$ & 51.0 & 59.0 & 54.5 & $54.1 \pm 2.1$ \\
\hline & Popliteal height & 44.5 & 52.0 & 47.8 & $48.1 \pm 2.8$ & 43.0 & 47.5 & 45.5 & $45.6 \pm 1.5$ \\
\hline & Buttock-popliteal height & 45.5 & 60.0 & 53.3 & $53.5 \pm 4.3$ & 47.5 & 59.0 & 56.0 & $55.4 \pm 3.5$ \\
\hline College & Height & 167.5 & 182.5 & 173.8 & $174.5 \pm 4.7$ & 160.0 & 170.0 & 164.0 & $164.2 \pm 3.1$ \\
\hline auditorium & Elbow height & 16.5 & 26.0 & 21.5 & $21.7 \pm 2.5$ & 16.0 & 24.5 & 19.5 & $19.9 \pm 2.5$ \\
\hline \multirow[t]{5}{*}{$n=31$} & Shoulder height & 53.5 & 70.0 & 60.5 & $61.1 \pm 4.2$ & 49.5 & 63.0 & 58.5 & $58.0 \pm 4$ \\
\hline & Upper arm length & 28.5 & 47.5 & 39.3 & $39.4 \pm 4.4$ & 32.5 & 42.0 & 38.5 & $38.1 \pm 2.4$ \\
\hline & Knee height & 51.0 & 61.5 & 55.8 & $56.1 \pm 2.8$ & 48.0 & 56.0 & 52.5 & $52.0 \pm 2.1$ \\
\hline & Popliteal height & 42.5 & 52.0 & 46.3 & $46.9 \pm 2.6$ & 40.5 & 46.5 & 43.5 & $43.2 \pm 1.5$ \\
\hline & Buttock-popliteal height & 49.5 & 61.5 & 53.8 & $54.2 \pm 3.4$ & 48.0 & 55.0 & 52.0 & $51.7 \pm 1.8$ \\
\hline Physiotherapy & Height & 170.5 & 178.0 & 176.8 & $175.5 \pm 3.4$ & 163.0 & 173.5 & $|7| .8$ & $170.0 \pm 4.8$ \\
\hline lecture theater & Elbow height & 17.5 & 22.5 & 19.3 & $19.6 \pm 2.1$ & 13.0 & 23.0 & 18.5 & $18.3 \pm 4.3$ \\
\hline \multirow[t]{5}{*}{$n=8$} & Shoulder height & 55.0 & 62.0 & 59.0 & $58.8 \pm 3.3$ & 54.5 & 63.0 & 58.5 & $58.6 \pm 3.6$ \\
\hline & Upper arm length & 36.0 & 42.5 & 39.0 & $39.1 \pm 2.7$ & 39.5 & 41.5 & 40.3 & $40.4 \pm 0.9$ \\
\hline & Knee height & 56.5 & 64.5 & 58.3 & $59.4 \pm 3.7$ & 54.0 & 63.5 & 57.0 & $57.9 \pm 4.5$ \\
\hline & Popliteal height & 47.0 & 54.5 & 49.5 & $50.1 \pm 3.4$ & 44.0 & 49.5 & 46.3 & $46.5 \pm 2.9$ \\
\hline & Buttock-popliteal height & 51.5 & 56.5 & 55.5 & $54.8 \pm 2.2$ & 49.0 & 55.0 & 52.5 & $52.3 \pm 2.9$ \\
\hline Statistics & Height & 174.0 & 188.0 & 179.5 & $180.5 \pm 4.8$ & 157.5 & 175.5 & 169.0 & $167.4 \pm 6.4$ \\
\hline lecture & Elbow height & 13.0 & 22.0 & 20.0 & $18.8 \pm 3.0$ & 17.5 & 26.0 & 19.5 & $20.3 \pm 2.8$ \\
\hline \multirow[t]{5}{*}{ theater $n=19$} & Shoulder height & 51.5 & 66.0 & 61.0 & $59.8 \pm 5.5$ & 51.5 & 63.0 & 60.0 & $58.8 \pm 3.6$ \\
\hline & Upper arm length & 32.0 & 46.5 & 41.0 & $4 I . I \pm 4.4$ & 33.5 & 42.5 & 39.0 & $38.5 \pm 3.1$ \\
\hline & Knee height & 53.5 & 62.0 & 57.5 & $57.2 \pm 2.4$ & 50.0 & 60.0 & 56.0 & $55.4 \pm 3.2$ \\
\hline & Popliteal height & 43.0 & 52.5 & 48.0 & $47.9 \pm 2.9$ & 43.0 & 51.5 & 46.3 & $46.4 \pm 2.3$ \\
\hline & Buttock-popliteal height & 48.0 & 57.5 & 52.0 & $52.6 \pm 3.1$ & 49.0 & 61.5 & 53.5 & $53.7 \pm 3.8$ \\
\hline Law lecture & Height & 172.0 & 188.5 & 178.5 & $179.0 \pm 4.5$ & 159.5 & 174.5 & 167.5 & $166.6 \pm 4.4$ \\
\hline \multirow[t]{6}{*}{ theater $n=44$} & Elbow height & 12.0 & 24.5 & 18.5 & $18.2 \pm 2.8$ & 13.5 & 30.0 & 17.5 & $18.2 \pm 3.9$ \\
\hline & Shoulder height & 51.0 & 66.5 & 59.3 & $58.8 \pm 3.8$ & 49.5 & 68.5 & 55.5 & $56.3 \pm 4.9$ \\
\hline & Upper arm length & 32.0 & 47.0 & 40.8 & $40.7 \pm 3.3$ & 30.0 & 43.0 & 38.5 & $38.1 \pm 2.9$ \\
\hline & Knee height & 54.5 & 64.5 & 58.5 & $59.0 \pm 2.6$ & 51.0 & 58.5 & 54.5 & $54.5 \pm 2.0$ \\
\hline & Popliteal height & 46.5 & 54.5 & 50.0 & $50.2 \pm 2.6$ & 44.0 & 53.5 & 48.0 & $47.6 \pm 2.3$ \\
\hline & Buttock-popliteal height & 50.5 & 59.5 & 53.5 & $54.0 \pm 2.7$ & 46.5 & 56.5 & 52.5 & $52.6 \pm 2.5$ \\
\hline Anthropology & Height & 162.5 & 178.0 & 172.0 & $170.6 \pm 6.0$ & 153.5 & 173.5 & 161.0 & $161.6 \pm 7.0$ \\
\hline lecture theater & Elbow height & 16.5 & 22.5 & 21.0 & $20.3 \pm 2.0$ & 13.0 & 26.5 & 20.0 & $20.2 \pm 4.3$ \\
\hline \multirow[t]{5}{*}{$n=14$} & Shoulder height & 51.0 & 62.0 & 58.0 & $57.1 \pm 3.7$ & 53.0 & 62.5 & 57.5 & $57.1 \pm 3.4$ \\
\hline & Upper arm length & 31.5 & 41.0 & 37.5 & $36.8 \pm 3.1$ & 31.0 & 41.5 & 36.5 & $36.9 \pm 3.6$ \\
\hline & Knee height & 50.5 & 59.0 & 54.0 & $54.3 \pm 2.9$ & 50.5 & 63.5 & 52.5 & $54.0 \pm 4.8$ \\
\hline & Popliteal height & 43.0 & 49.0 & 46.5 & $46.2 \pm 2.4$ & 43.0 & 49.5 & 44.5 & $45.4 \pm 2.4$ \\
\hline & Buttock-popliteal height & 46.5 & 53.0 & 52.0 & $50.9 \pm 2.3$ & 44.5 & 55.0 & 51.0 & $50.1 \pm 3.9$ \\
\hline Physiology & Height & 173.0 & 181.5 & 177.0 & $177.0 \pm 3.2$ & 157.0 & 174.0 & 162.0 & $163.2 \pm 5.9$ \\
\hline lecture & Elbow height & 16.0 & 23.5 & 21.0 & $20.4 \pm 3.6$ & 17.0 & 22.0 & 20.0 & $20.0 \pm 1.9$ \\
\hline \multirow[t]{5}{*}{ theater $n=14$} & Shoulder height & 52.5 & 64.0 & 60.0 & $59.4 \pm 3.5$ & 54.0 & 58.0 & 57.0 & $56.0 \pm 1.9$ \\
\hline & Upper arm length & 32.0 & 44.0 & 40.0 & $39.0 \pm 4.2$ & 32.0 & 39.0 & 36.0 & $36.0 \pm 2.4$ \\
\hline & Knee height & 51.5 & 65.0 & 57.5 & $57.5 \pm 4.9$ & 49.5 & 60.0 & 52.5 & $53.4 \pm 3.8$ \\
\hline & Popliteal height & 43.5 & 51.0 & 47.0 & $47.3 \pm 2.5$ & 43.0 & 51.0 & 44.5 & $45.5 \pm 2.8$ \\
\hline & Buttock-popliteal height & 51.0 & 59.5 & 54.5 & $54.1 \pm 3.0$ & 48.5 & 56.0 & 51.0 & $51.7 \pm 2.7$ \\
\hline
\end{tabular}


Table 2 (Continued)

\begin{tabular}{|c|c|c|c|c|c|c|c|c|c|}
\hline \multirow[t]{2}{*}{ Venue } & \multirow{2}{*}{$\begin{array}{l}\text { Anthropometric } \\
\text { dimension }\end{array}$} & \multicolumn{4}{|l|}{ Male } & \multicolumn{4}{|c|}{ Female } \\
\hline & & $\begin{array}{l}\text { Min } \\
\text { value }\end{array}$ & $\begin{array}{l}\text { Max } \\
\text { value }\end{array}$ & Median & $\begin{array}{l}\text { Mean } \\
(\text { mean } \pm S D)\end{array}$ & $\begin{array}{l}\text { Min } \\
\text { value }\end{array}$ & $\begin{array}{l}\text { Max } \\
\text { value }\end{array}$ & Median & $\begin{array}{l}\text { Mean } \\
(\text { mean } \pm S D)\end{array}$ \\
\hline Faculty of Social & Height & 171.0 & 187.0 & 176.0 & $177.2 \pm 5.4$ & 157.0 & 169.5 & 161.8 & $163.1 \pm 4.3$ \\
\hline Science lecture & Elbow height & 16.5 & 22.5 & 19.5 & $19.6 \pm 1.7$ & 16.0 & 24.0 & 21.0 & $20.7 \pm 2.3$ \\
\hline \multirow[t]{5}{*}{ theater $n=24$} & Shoulder height & 54.0 & 66.0 & 60.5 & $60.3 \pm 3.4$ & 53.0 & 60.0 & 57.8 & $57.2 \pm 2.3$ \\
\hline & Upper arm length & 35.5 & 46.0 & 40.5 & $40.7 \pm 2.4$ & 31.5 & 39.0 & 36.0 & $36.5 \pm 2.4$ \\
\hline & Knee height & 53.5 & 62.0 & 57.8 & $57.6 \pm 3.2$ & 49.5 & 56.5 & 52.5 & $52.6 \pm 2.4$ \\
\hline & Popliteal height & 43.0 & 51.5 & 47.3 & $47.5 \pm 2.6$ & 40.0 & 46.5 & 44.3 & $44.4 \pm 1.9$ \\
\hline & Buttock-popliteal height & 48.0 & 57.0 & 53.5 & $53.6 \pm 2.8$ & 48.5 & 59.0 & 51.0 & $51.5 \pm 2.8$ \\
\hline Faculty of & Height & 155.0 & 192.0 & 173.0 & $173.3 \pm 8.7$ & 157.3 & 187.0 & 169.0 & $168.5 \pm 7.2$ \\
\hline Science lecture & Elbow height & 14.5 & 25.5 & 18.5 & $19.2 \pm 3.0$ & 13.5 & 22.5 & 18.5 & $17.9 \pm 2.8$ \\
\hline \multirow[t]{5}{*}{ theater $n=29$} & Shoulder height & 52.5 & 63.5 & 57.5 & $57.6 \pm 3.4$ & 51.5 & 66.5 & 56.5 & $57.0 \pm 3.8$ \\
\hline & Upper arm length & 32.0 & 44.5 & 38.5 & $38.4 \pm 3.3$ & 36.0 & 44.5 & 38.8 & $39.1 \pm 2.2$ \\
\hline & Knee height & 50.5 & 63.0 & 56.5 & $56.7 \pm 3.7$ & 52.0 & 62.0 & 55.8 & $56.1 \pm 2.3$ \\
\hline & Popliteal height & 42.0 & 53.5 & 47.5 & $47.1 \pm 3.0$ & 42.0 & 51.5 & 46.3 & $46.2 \pm 2.4$ \\
\hline & Buttock-popliteal height & 48.5 & 59.5 & 54.0 & $53.9 \pm 3.2$ & 50.0 & 55.5 & 54.0 & $53.6 \pm 1.5$ \\
\hline Faculty of & Height & 176.5 & 191.0 & 179.8 & $18 \mid .6 \pm 5.5$ & 164.5 & 172.0 & 166.3 & $167.4 \pm 2.8$ \\
\hline Agricultural & Elbow height & 12.0 & 19.0 & 16.3 & $16.3 \pm 2.4$ & 15.5 & 21.5 & 18.0 & $18.3 \pm 2.1$ \\
\hline Science lecture & Shoulder height & 58.5 & 63.0 & 59.8 & $60.3 \pm 1.6$ & 55.5 & 61.0 & 58.0 & $57.9 \pm 2.3$ \\
\hline theater & Upper arm length & 41.5 & 47.0 & 43.5 & $44.0 \pm 2.3$ & 34.0 & 41.5 & 40.5 & $39.7 \pm 2.9$ \\
\hline \multirow[t]{3}{*}{$n=12$} & Knee height & 53.0 & 63.5 & 58.8 & $58.9 \pm 3.6$ & 33.0 & 58.5 & 54.8 & $51.6 \pm 9.4$ \\
\hline & Popliteal height & 47.0 & 54.5 & 50.3 & $50.5 \pm 2.7$ & 46.5 & 51.5 & 47.5 & $48.5 \pm 2.2$ \\
\hline & Buttock-popliteal height & 49.0 & 56.0 & 53.0 & $52.8 \pm 2.8$ & 49.0 & 54.5 & 51.3 & $51.4 \pm 2.3$ \\
\hline Chemistry & Height & 170.5 & 195.0 & 177.3 & $177.6 \pm 7.6$ & 162.0 & 174.5 & 167.0 & $166.9 \pm 4.2$ \\
\hline lecture theater & Elbow height & 16.0 & 23.5 & 18.8 & $19.2 \pm 3.1$ & 16.5 & 26.0 & 22.5 & $22.1 \pm 3.4$ \\
\hline \multirow[t]{5}{*}{$n=16$} & Shoulder height & 52.5 & 64.0 & 59.0 & $59.0 \pm 4.5$ & 54.0 & 61.5 & 59.0 & $58.6 \pm 2.5$ \\
\hline & Upper arm length & 32.0 & 48.0 & 39.3 & $39.8 \pm 4.8$ & 33.0 & 39.5 & 36.0 & $36.5 \pm 2.4$ \\
\hline & Knee height & 51.5 & 67.0 & 57.8 & $58.4 \pm 4.9$ & 50.5 & 60.5 & 55.0 & $54.9 \pm 2.9$ \\
\hline & Popliteal height & 45.5 & 58.0 & 47.5 & $48.8 \pm 4.0$ & 43.0 & 50.0 & 45.3 & $45.9 \pm 2.3$ \\
\hline & Buttock-popliteal height & 50.0 & 60.5 & 54.3 & $54.8 \pm 3.5$ & 49.5 & 62.5 & 54.5 & $55.9 \pm 5.0$ \\
\hline
\end{tabular}

Abbreviations: Max, maximum values; Min, minimum values; $n$, number of participants; SD, standard deviation.

highest variation within the male $( \pm 6.3 \mathrm{~cm})$ and female participants $( \pm 5.6 \mathrm{~cm})$.

\section{Mismatch of student body dimensions with seat and writing surface dimensions}

The percentage mismatch of the seats and writing surface with the anthropometric dimensions of all the participants is shown in Figure 1. Mismatches are illustrated in Figures 2-8.

- Popliteal-seat height mismatch: the seat height was too low for $61.3 \%$ of the participants, fit for $19.6 \%$ of the participants, and too high for $19.2 \%$ of the participants in this study.

- Buttock-popliteal seat depth mismatch: the seat depth was too shallow for $76.3 \%$ of the participants, fit for $23.3 \%$ of the participants, and too deep for the rest of the $0.4 \%$ of participants.

- Knee-desk height mismatch: the desk was fit for $99.6 \%$ of the participants, but was too low for $0.4 \%$ of the participants.
- Elbow-desk height mismatch: the elbow-desk height was high for $73.3 \%$ of the participants, fit for $25.8 \%$ of the participants, and too low for the remaining $0.8 \%$ of the participants in this study.

\section{Mismatch based on seat height and seat depth combinations}

The seats in the Paul Hendrickse lecture theater were too short and too shallow for $86 \%$ of the participants, and too short but fitting depth for $14 \%$ of the participants. The college auditorium had seats that were too shallow and too short for $77 \%$ of the participants, and too short but fitting depth for $23 \%$ of the participants. In the physiotherapy lecture theater, the seats were too shallow and too short for $75 \%$ of the participants, while being too shallow but fitting height for $25 \%$ of the participants. The statistics lecture theater had seats which were too shallsow and too short for $90 \%$ of the participants, and fitting depth too low 


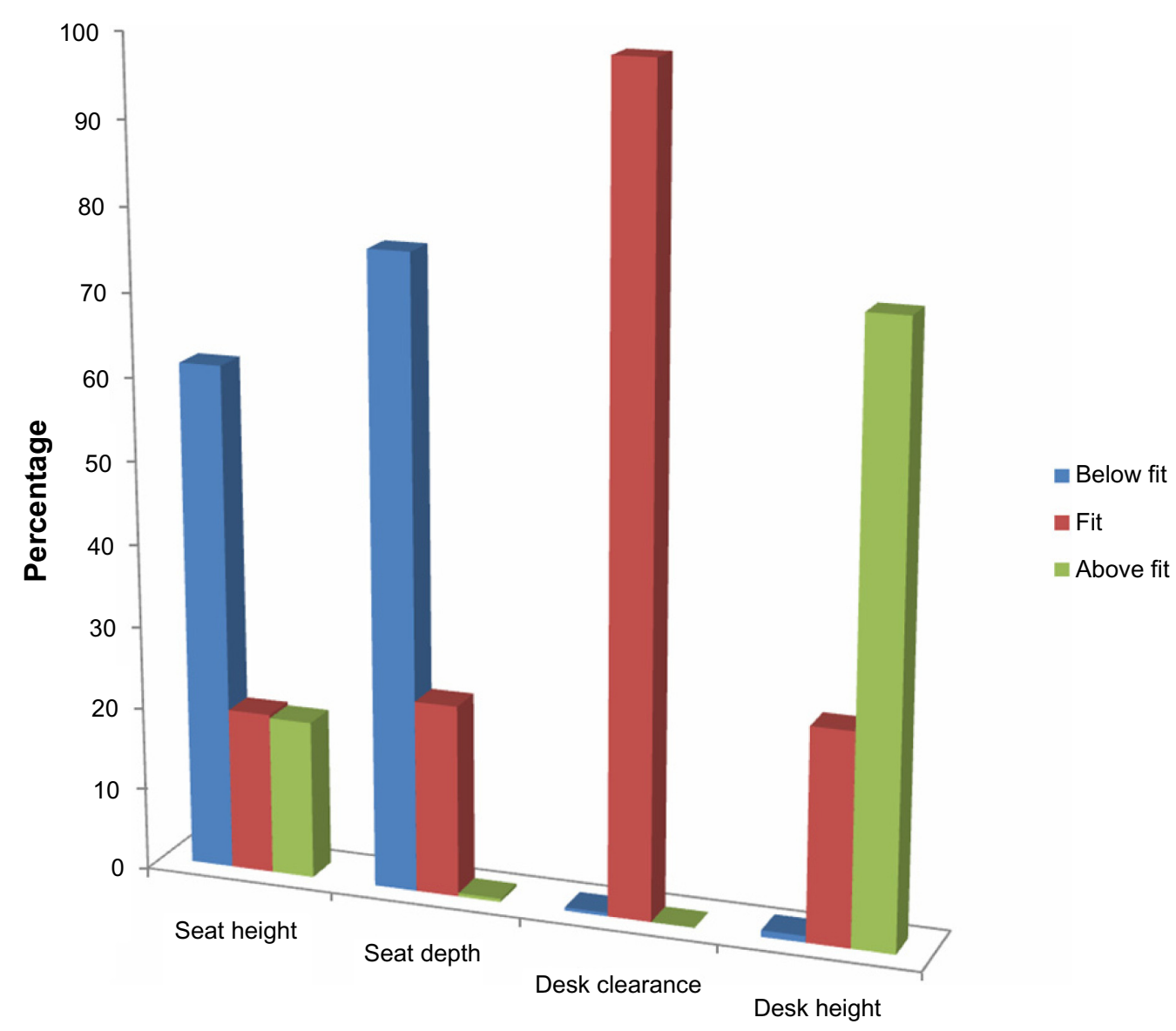

Figure I Percentage suitability of the seat and writing surfaces for all participants.

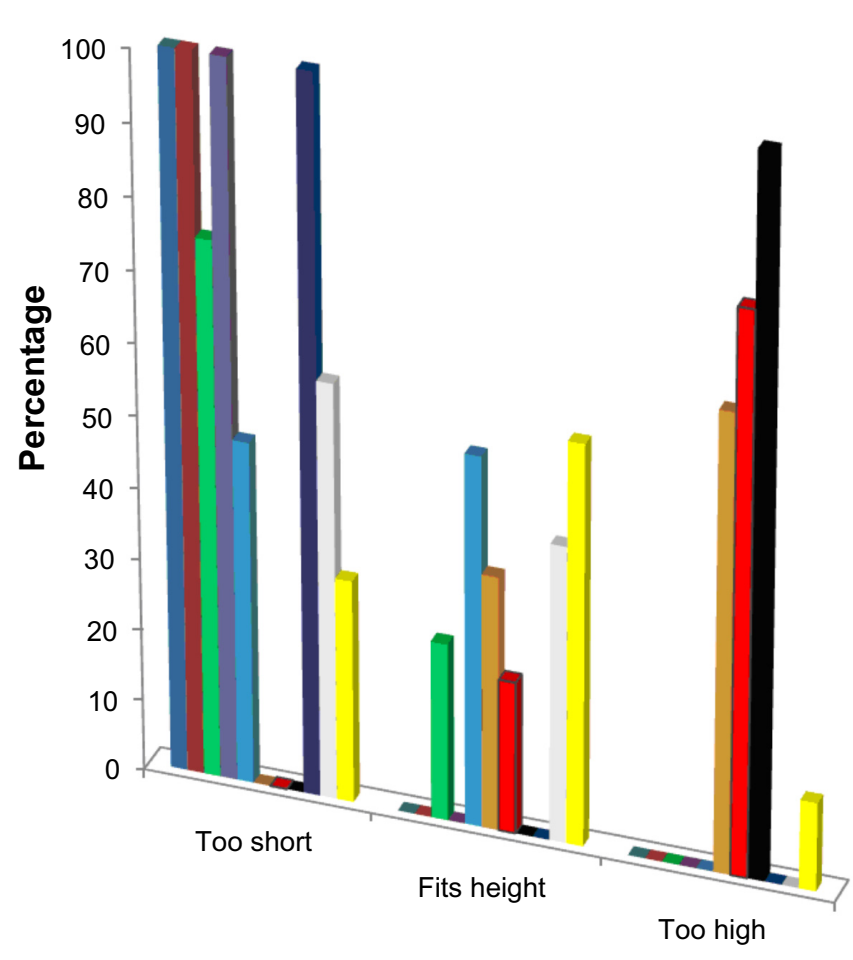

- Paul Hendrickse lecture theater

College auditorium

n Physiotherapy lecture theater

n Statistics lecture theater

- Law lecture theater

\#nthropology lecture theater

- Physiology lecture theater

- Faculty of Social Science lecture theater

- Faculty of Science lecture theater

Faculty of Agricultural Science lecture theater

Chemistry lecture theater

Figure 2 Percentage popliteal-seat height mismatch for the students classified by lecture venue. 


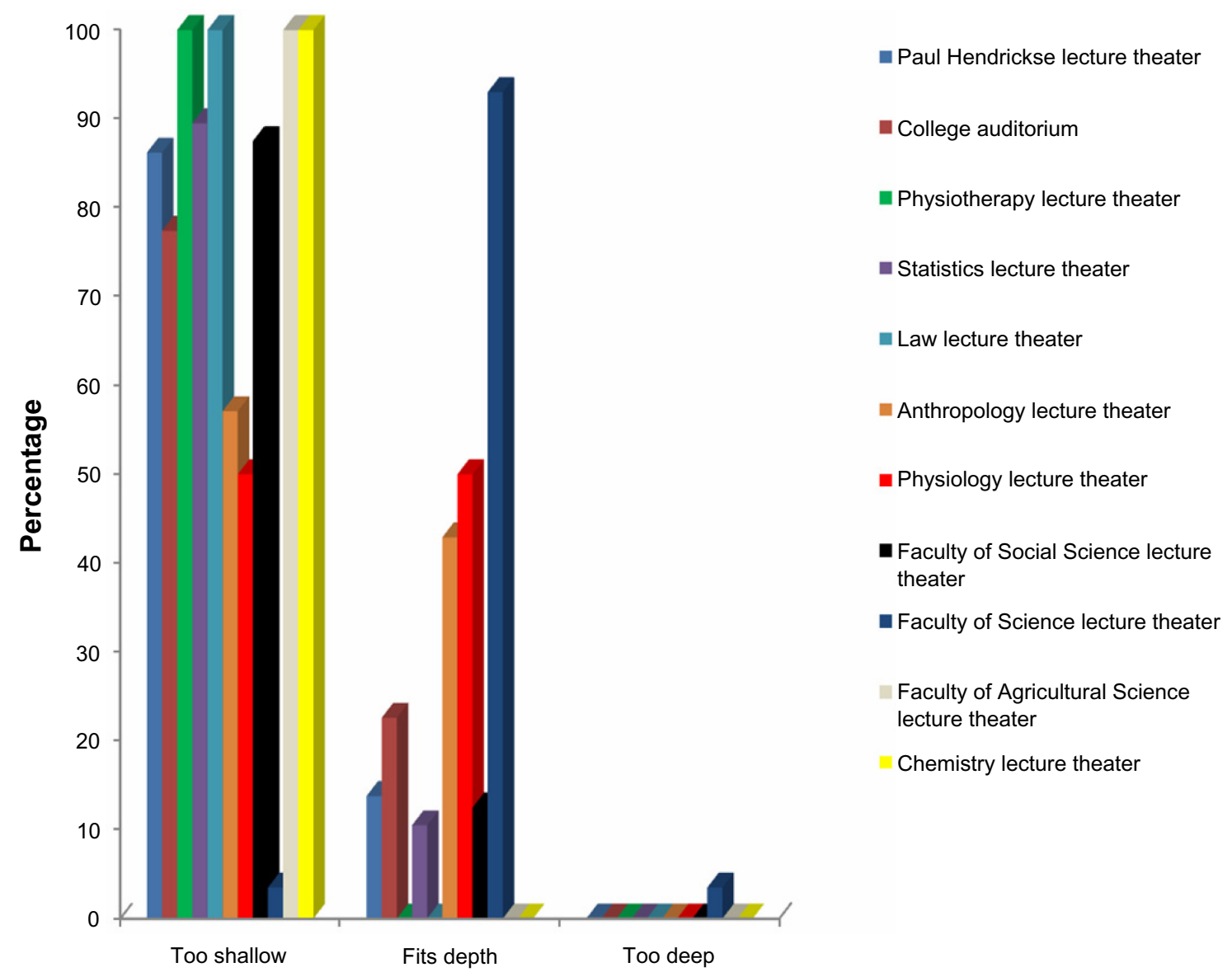

Figure 3 Percentage buttock-popliteal seat depth mismatch classified by lecture venue.

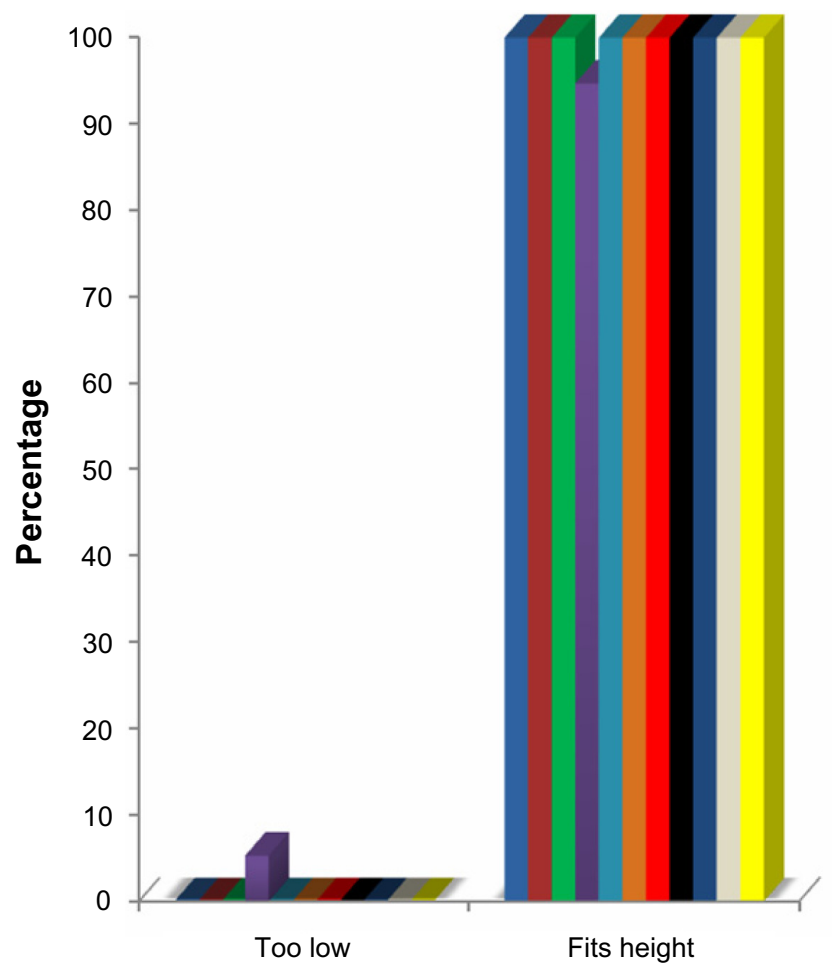

- Paul Hendrickse lecture

College auditorium

- Physiotherapy lecture theater

- Statistics lecture theater

- Law lecture theater

anthropology lecture theater

- Physiology lecture theater

- Faculty of Social Science lecture theater

- Faculty of Science lecture theater

Faculty of Agricultural Science lecture theater

Chemistry lecture theater

Figure 4 Percentage knee-desk clearance mismatch for students classified by lecture venue. 


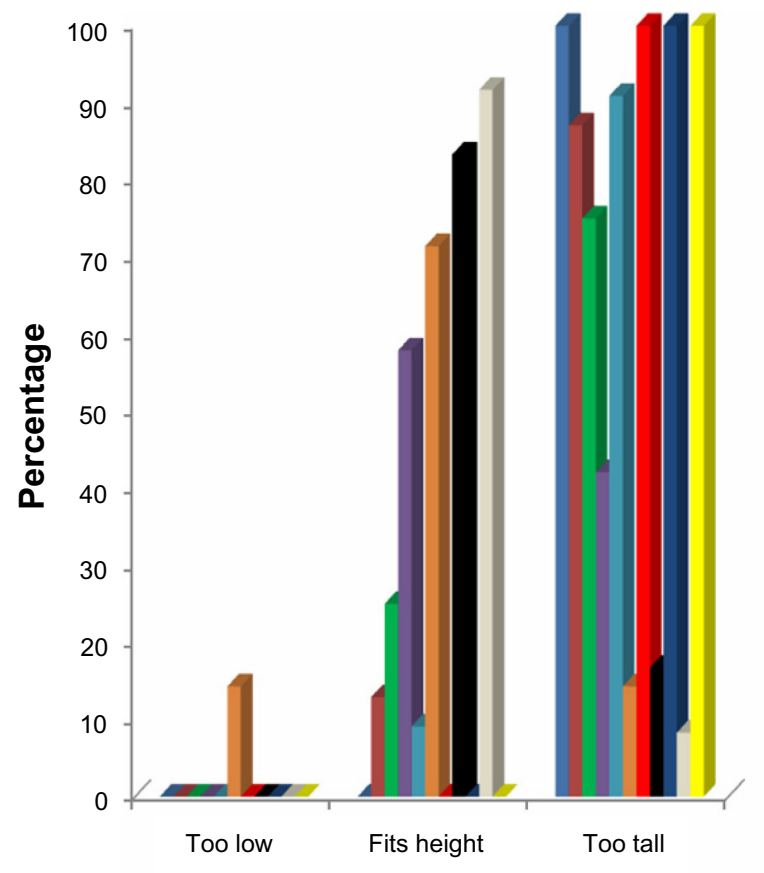

- Paul Hendrickse lecture theater

n College auditorium

- Physiotherapy lecture theater

- Statistics lecture theater

naw lecture theater

Anthropology lecture theater

- Physiology lecture theater

- Faculty of Social Science lecture theater

Faculty of Science lecture theater

Faculty of Agricultural Science lecture theater

Chemistry lecture theater

Figure 5 Percentage elbow-desk height mismatch for students classified by lecture venue.

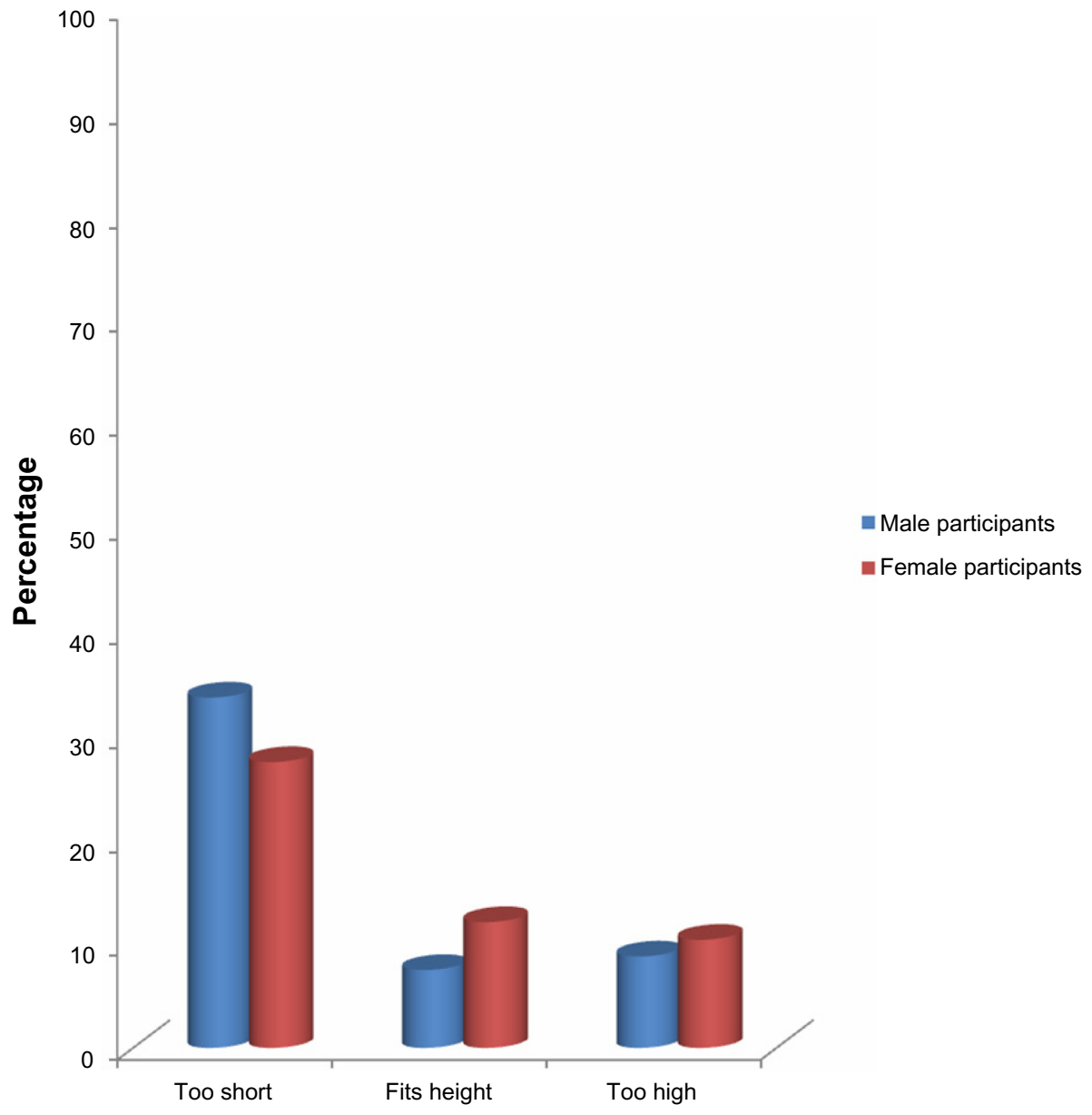

Figure 6 Percentage popliteal-seat height mismatch for all participants classified by sex. 


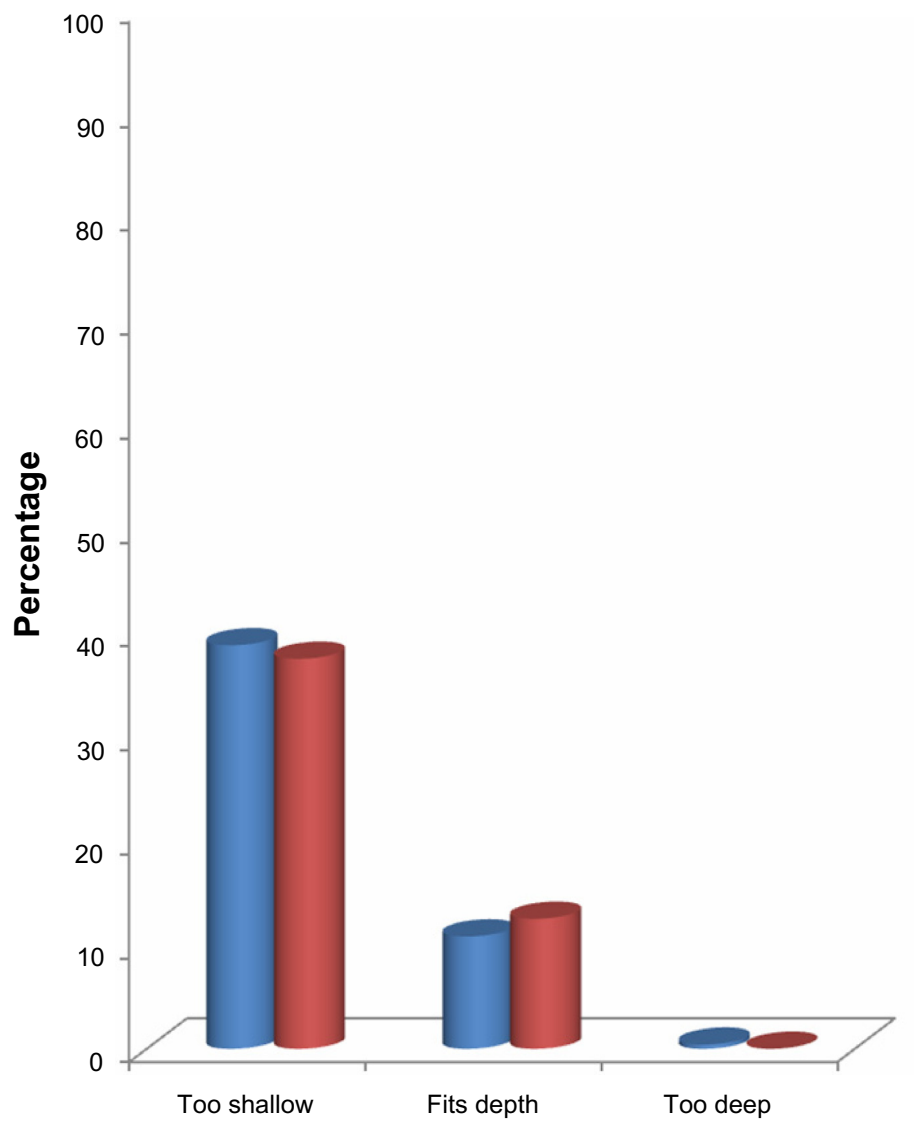

Figure 7 Percentage buttock-popliteal height mismatch of all participants classified by sex.

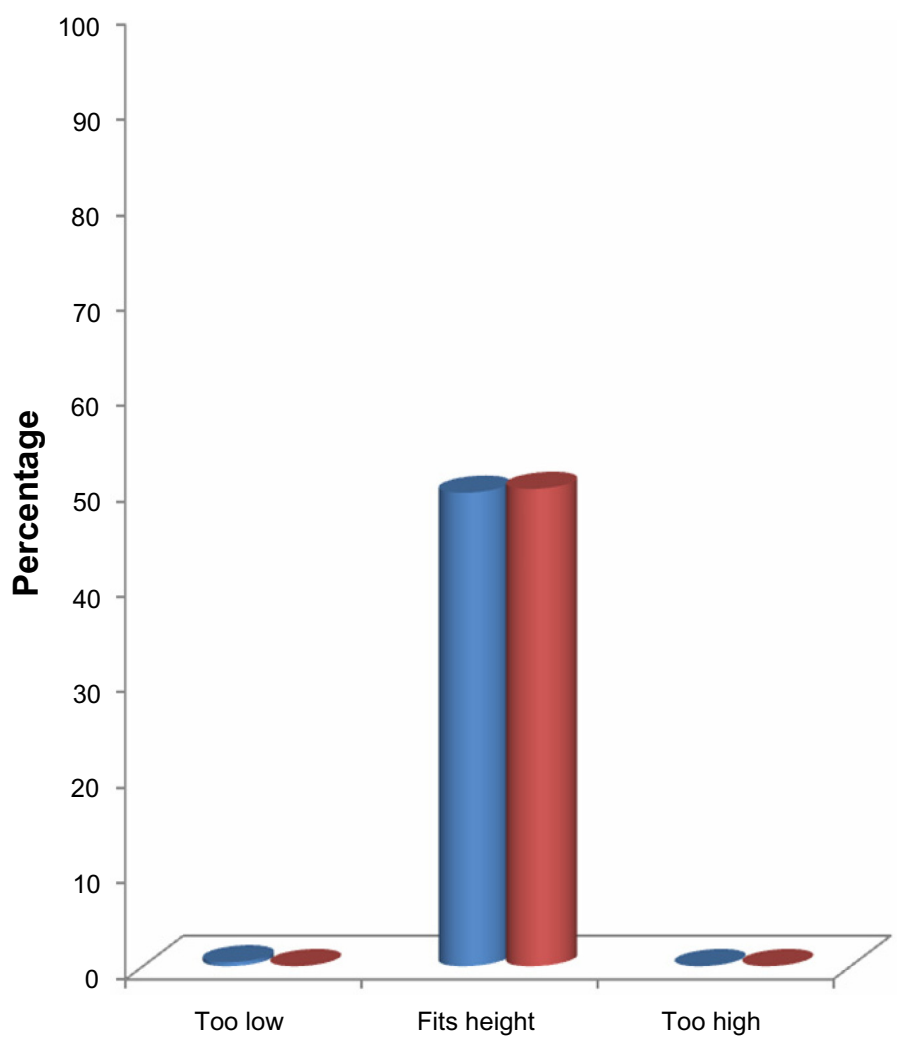

Male participants

a Female participants
Male participants

- Female participants

Figure 8 Percentage knee-desk clearance mismatch for all participants classified by sex. 


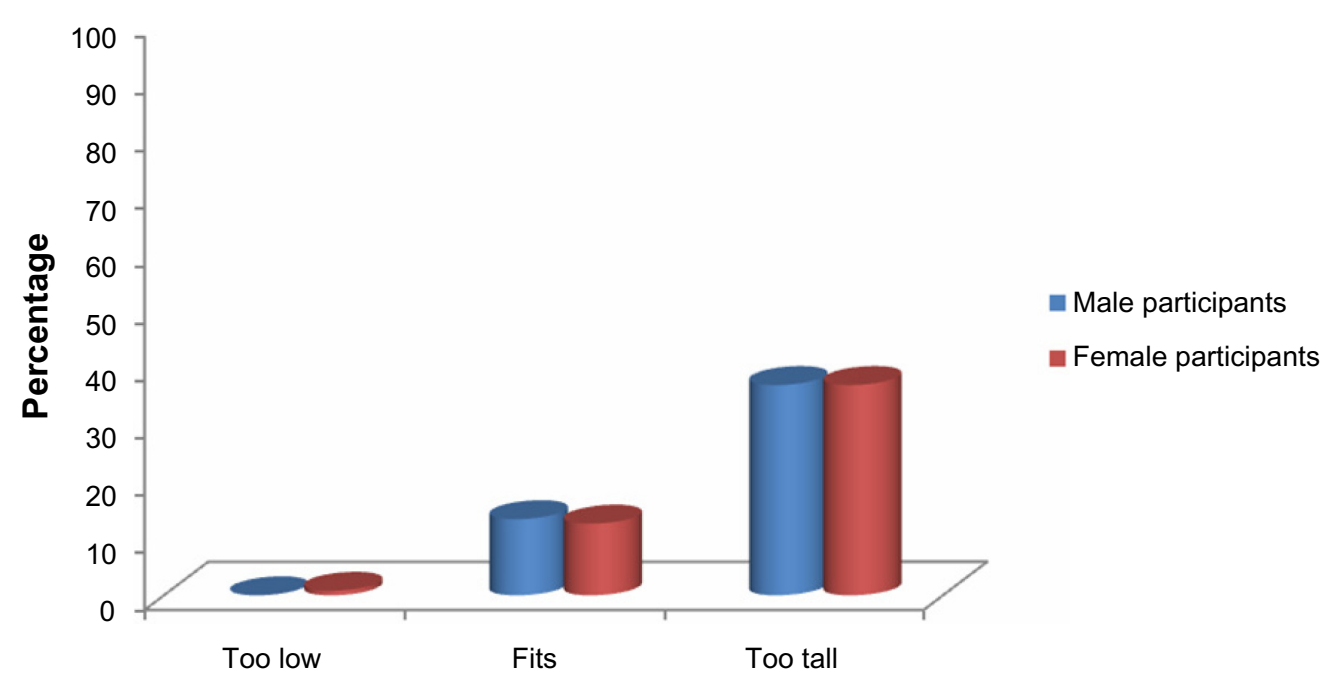

Figure 9 Percentage elbow-desk height clearance for all participants classified by sex.

for $10 \%$ of the participants. In the law lecture theater, the seats were too low but fit height for $52 \%$ of the participants, and were too short and too shallow for $48 \%$ of the participants. The seats were too high but fit depth for $36 \%$ of the participants in the anthropology lecture theater; $28.5 \%$ of the participants had the seats too high but shallow and fit height but, while $7 \%$ of the participants had the seat fit in depth and height. For the physiology lecture theater, the seats were too high but fitting depth for $50 \%$ of the participants, too high but too shallow for $28.5 \%$ of the participants, and fitting height but too shallow for $21.5 \%$ of the participants. In the Faculty of Social Science lecture theater, $87.5 \%$ of the participants had the seat too high and too shallow, while $12.5 \%$ had the seat too high but fitting in depth. In the Faculty of Science lecture theater, $93 \%$ of the participants had the seat too short but fitting depth; $3.5 \%$ had the seat too short and too shallow; $3.5 \%$ found the seat too short and too deep. In the Faculty of Agricultural Science lecture theater, $58.3 \%$ of the participants had the seats too short and too shallow, and $42.7 \%$ of the participants found the seats fit height but were too shallow. Lastly, in the chemistry lecture theater, $56.2 \%$ of the participants had the seat fitting height but too shallow; the seat was too short and too shallow for $31.3 \%$ of the participants, and $12.5 \%$ of the participants had the seat too high and too shallow. The seat height and seat depth was fit for only $0.4 \%$ of participants in this study.

\section{Discussion}

This study involved young adults in the University of Ibadan and examined eleven lecture theaters with furniture of different designs and dimensions.

\section{Furniture design}

The selected lecture theaters that have cushioned seats which are retractable are estimated at $66.6 \%$. According to Eckelman et al, seats with cushion design are more ergonomically suitable than wooden design, while seats with metal design are the least suitable. ${ }^{18}$ Hence $63.6 \%$ of the lecture theaters are suitable in terms of practicality and comfort. Only one of the selected lecture theaters had cushioned seats that were not retractable, and had suitable detachable writing platforms; this is in accordance with Mandal, as those seats were suitable in practicality and comfort. ${ }^{19}$ The lecture theaters that had seat surfaces made of unpadded wood with retractable seats constituted $9.1 \%$ of the selected lecture theaters. According to Mandal, seats with this design do not offer comfort to the users. Hence the furniture design of the lecture theaters is suitable in practicality because of the retractable seat but not in comfortability. The lecture theaters with seat surfaces made of metal constituted $9.1 \%$ of the lecture theaters, and they had the least comfort and practicality. The selected lecture theaters having nonretractable and unpadded wooden seats, with a fixed writing surface attached anteriorly, also constituted $9.1 \%$ of the lecture theaters, and are unsuitable in both practicality and comfort. It was observed that various lecture theaters had different designs. The more recently constructed lecture theaters had more suitable designs than the older lecture theaters. This difference may be attributed to the varying level of knowledge of ergonomics at the different times when the lecture theaters were constructed, as long as 60 years ago for the older university lecture theaters.

\section{Orientation of lecture theater furniture}

The selected lecture theaters that had a curved-tier-floor orientation were estimated at $56.6 \%$, while $36.4 \%$ of the selected 
theaters had a horizontal-tier-floor orientation; therefore, 91\% of lecture theaters at the university are suitable in orientation since they have tiers which enhance sound and viewing effect as opined by Smawfield..$^{20}$ One $(9 \%)$ of the selected lecture theaters had a level floor orientation, and consequently, sound effects and viewing capacity will be considerably reduced. Hence this lecture theater is unsuitable in relation to furniture orientation. The lecture theater which had a level floor orientation is an old lecture theater constructed when the university was founded, and the design orientation has not been reconstructed since the inception.

\section{Anthropometric dimensions of the students}

The mean height of the male participants was higher than that of the female participants in all lecture theaters. However, the mean of elbow height, knee height, shoulder height, upper arm length, popliteal height, and buttock-popliteal length were within the same range for male and female participants. There was a significant difference in the height $(P=0)$, knee height $(P=0)$, popliteal height $(P=0)$, shoulder height $(P=0)$, and upper arm length $(P=0)$ between all male and female participants. There was however no significant difference in elbow height $(P=0.674)$ and buttock-popliteal height $(P=0.069)$ between all male and female participants. According to Parcells et al, height was not a strong predictor of furniture fitness to an individual's body dimension. ${ }^{16}$ For this study, it can be inferred that since the mean of every measure, except for height, was within a range of $4 \mathrm{~cm}$ for male and female participants, furniture which will fit the majority of the students at the University of Ibadan can be designed using these variables.

\section{Suitability of the seats and writing surface dimensions to student body dimensions}

The seat height was too low for $61.2 \%$ of the participants in $72.7 \%$ of the selected lecture theaters. According to Saarni et al, seats that are too low result in the adoption of a kyphotic posture by the users while writing. ${ }^{21}$ A suitable chair, as the authors explain, helps to establish a correct sitting posture, such that the lordotic and kyphotic curves of the spine are maintained. Hence, the seats in these lecture theaters are unsuitable. The seat height was fit for $19.6 \%$ of the participants in $54.6 \%$ of the selected lecture theaters, and they were too high for $19.2 \%$ of the participants in $27.3 \%$. Panagiotopoulou et al reported that seats that were too high were unsuitable, as they caused students to conform to a kyphotic posture. ${ }^{22}$ This is in agreement with the report by Castellucci et al, in that chairs that were too high yielded an increased incidence of lower back pain among students. ${ }^{23}$ The seats were too shallow for $76.3 \%$ of the participants in $100 \%$ of the lecture theaters. According to Agha, seats that were too shallow were unsuitable, as they increased muscular work in the back while trying to maintain equilibrium. ${ }^{24}$ Panagiotopoulou et al also reported that seats that were too shallow increased muscle work, thus increasing fatigue and discomfort. ${ }^{22}$ In agreement with these studies, a shallow seat depth is unsuitable. The seat depth was fit for $23.3 \%$ of the participants in $63.6 \%$ of the selected lecture theaters. The seats were too deep for one participant $(0.4 \%)$ in one $(9.1 \%)$ of the selected lecture theaters.

According to Castellucci et al, seats that are too deep are unsuitable, as they cause compression of the popliteal fossa and lead to the adoption of a faulty posture. ${ }^{23}$ The desk clearance was too low for one $(0.4 \%)$ participant in one $(9.1 \%)$ of the selected lecture theaters. The desk clearance was fit for $99.6 \%$ of the students in all the selected lecture theaters. The desk height was too low for $0.8 \%$ of the participants in $9.1 \%$ of the selected lecture theaters, fit for $25.8 \%$ of the participants in $63.6 \%$, and too high for $73.4 \%$ of the participants. According to Gouvali and Boudolos, desks that are too tall were unsuitable, as they required children to flex their shoulders more than 25 degrees and abduct them more than 20 degrees in order to support their elbows, thereby resulting in quick onset of fatigue in the muscles of the upper limbs. ${ }^{25}$ In summary, $80.4 \%$ of the participants found the seat height unsuitable, while $19.6 \%$ of the participants found it suitable. The seat depth was unsuitable for $76.7 \%$ of the participants, while $23.3 \%$ of the participants found it suitable. The desk clearance was suitable for $99.6 \%$ of the participants but unsuitable for $4 \%$ of the participants. The desk height was unsuitable for $74.2 \%$ of the participants but suitable for $25.8 \%$ of the participants in this study. Milanese and Grimmer reported that there exists an optimal anthropometric/furniture dimension relationship, and deviations from that optimal relationship among a vast majority of the population will make the furniture unsuitable. ${ }^{26}$ In agreement with this finding, it can be concluded that the desk clearance is the only suitable furniture dimension, while the desk height, seat height, and seat depth are unsuitable for the students at the university.

\section{Suitability based on seat height and seat depth combination}

Seventy-five percent of the participants found the seats too short and too shallow. In the students' opinion, the seats were 
"too short but fitting depth"; "fitting height but too shallow"; "fitting height but too deep"; "too high and too shallow"; and "too high but fitting depth" for $24.6 \%$ of the participants. This may be due to the variability of furniture dimensions in the lecture theaters at the University of Ibadan. Only $0.4 \%$ of the entire sample population of students found seats that fit both height and depth. It has been shown that furniture with very low percentage of fit among a population is unsuitable, and must have been constructed without ergonomic consideration for that population. ${ }^{23}$ It is observed that the seats at the University are unsuitable, and the reason for this is that adequate ergonomic consideration was not given in the construction of the lecture theaters at the university.

\section{Suitability based on desk height and desk clearance}

Desks were fit in clearance and in height for $25.5 \%$ of the participants. Similar findings were obtained by Parcells et al, ${ }^{16}$ Panagiotopoulou et al, ${ }^{22}$ and $\mathrm{Agha}^{24}$ who had the furniture fit for the minority of the students. The desks were fit in clearance but had a low height for $0.8 \%$ of the participants, and were low in clearance but fit in height for $0.4 \%$ of the participants in this study. The desks were fit in clearance but too tall in height for $73.3 \%$ of the participants.

It is important to note at this point that these findings may present challenging health implications. The students attending lectures at various theaters of the University of Ibadan may be faced with musculoskeletal problems such as neck pain, back pain, etc. Besides these health hazards, learning problems could be another challenge. When a student sits in an uncomfortable seat and experiences musculoskeletal problems, either as a result of muscle fatigue or musculoskeletal pain, the student may lose concentration, which may culminate in poor academic performance. ${ }^{18}$ As the University of Ibadan is one the best universities in Nigeria with regard to infrastructure, we envisage that these findings will likely be similar or worse in other universities in the country. It will be necessary to assess the prevalence of musculoskeletal and learning problems due to improper furniture among students in Nigerian universities.

\section{Conclusion}

Based on the results of this study, it was concluded that the design and dimension combination of furniture in each of the lecture theaters is ergonomically unsuitable for the students at the University of Ibadan. The university had different designs of furniture which were not appropriate. There were eleven types of dimension combinations and none was fitting for up to $50 \%$ of the participants. The results of this study provide baseline information on the anthropometric measurements of students at the university level and also on the suitability of the lecture theaters. Moreover, the results probably reflect the conditions at other universities in our society.

\section{Recommendations}

This study has identified a major challenge to health and learning of students at the University of Ibadan. We know that resources may place limitations on providing proper furniture; however, we also believe that lack of knowledge about suitability of furniture could cause an institution with resources to provide improperly designed furniture to their students. There is a need to gather student anthropometric data which is presently lacking, but gradually, we could work toward providing a better learning environment. Conducting similar studies in other Nigerian universities would be an appropriate strategy to this end. In addition, determining the health and learning problems associated with improperly designed furniture is also necessary. Such studies would help to develop an anthropometric standard for Nigerian students, which will serve as useful information for the construction of school furniture in higher institutions, and inform policy making at the university managerial level in working toward adequate ergonomic consideration before the construction of furniture in lecture theaters.

\section{Disclosure}

The authors report no conflicts of interest in this work.

\section{References}

1. Patron DD. Classroom ergonomics implications for health, safety and academic performance [webpage on the Internet]. Huntington Valley, PA: The Free Library; 2009. Available from: http://www.thefreelibrary.com/ Classroom+Ergonomics+Implications+for+Health,+Safety+\%26+Acad emic...-a01073984348. Accessed November 11, 2013.

2. Occhipinti E, Colombini D, Molteni G, Grieco A. Criteria for the ergonomic evaluation of work chairs. Med Lav.1993;84(4):274-285.

3. Lefler RK. Office chair: choosing the right ergonomic office chair [webpage on the Internet]. Deerfield, IL: Spine-health; 2010. Available from: http://www.spine-health.com/wellness/ergonomics/officechair-choosing-right-ergonomic-office-chair. Accessed January 24, 2011.

4. Lane KE, Richardson MD. Human factors engineering and school furniture: a circular odyssey. Educ Facil Plan. 1993;31(3):22-23.

5. Olsen TL, Anderson RL, Dearwater SR, et al. The epidemiology of low back pain in an adolescent population. Am J Public Health. 1992;82(4): 606-608.

6. Amick BC 3rd, Robertson MM, DeRango K, et al. Effect of office ergonomics intervention on reducing musculoskeletal symptoms. Spine (Phila Pa 1976). 2003;28(24):2706-2711.

7. Alrowayeh HN, Alshatti TA, Aljadi SH, Fares M, Alshamire MM, Alwazan SS. Prevalence, characteristics and impacts of work-related musculoskeletal disorders: a survey among physical therapists in the State of Kuwait. BMC Musculoskelet Disord. 2010;11:116. 
8. Kahya E. The effects of job characteristics and working conditions on job performance. Int J Indust Ergon. 2007;37(6):515-523.

9. Sikiru L, Hanifa S. Prevalence and risk factors of low back pain among nurses in a typical Nigerian hospital. Afr Health Sci. 2010;10(1): 26-30.

10. Silverstein B, Adams D. Work-related musculoskeletal disorders of the neck, back, and upper extremity in Washington State, 1996-2004. Technical Report Number 40-10a-2006. Olympia, WA: Safety and Health Assessment and Research for Prevention Washington State Department of Labor and Industries; 2006. Available from: http://www.lni.wa.gov/ Safety/Research/Files/WmsdFinal.pdf. Accessed July 10, 2011.

11. Foley M, Silverstein B. Employer survey on musculoskeletal injuries and illnesses, risk factors and prevention steps in Washington State workplaces. SHARP Technical report executive summary January 1999. Olympia, WA. Available from: www.LNI.wa.gov/Safety/Research/files/ ergosurv.pdf. Accessed July 15, 2011.

12. Ismaila SO. Anthropometric data of the foot of Nigerian university students. Ergon SA. 2008;20(2):45-50.

13. Yisa GM. Ergonomics in small-scale grain mills in Nigeria. Afr Newlett Occup Health and Safety. 2005;15:7-10.

14. Yamane T. Statistics: An Introductory Analysis. 2nd ed. New York, NY: Harper and Row; 1967.

15. Ghazzilla RAR, Taha Z, Kamaruddin S, Hasanuddin I. Pilot investigation on the mismatches of classroom furniture and student body dimensions in Malaysian secondary schools. $J$ Soc Sci. 2010;6(2):287-292.

16. Parcells C, Stommel M, Hubbard RP. Mismatch of classroom furniture and body dimensions: empirical findings and health implications. J Adolesc Health. 1999;24(4):265-273.
17. Chaffin DB, Anderson GBJ. Occupational Biomechanics. 2nd ed. Hoboken, NJ: John Wiley \& Sons; 1991.

18. Eckelman C, Haviarova E, Zui H, Gibson H. Consideration in design and development of school furniture for developing regions based on local resources. Forest Product Journal. 2001;51(6):56-63.

19. Mandal T. Better furniture types for work and studies reduce bending and pain. Available from: www.bodyconsciousdesign.com/uploads/ mandal_article.pdf. Accessed July 10, 2011.

20. Smawfield D. A position paper on the implications of classroom furniture design choices for raising educational standards in Turkish primary schools [webpage on the Internet]. 2007. Available from: http://www. scribd.com/doc/118244922/Classroom-Furniture-Design-Choices. Accessed June 16, 2011.

21. Saarni L, Nygård CH, Kaukiainen A, Rimpela A. Are the desks and chairs at school appropriate? Ergonomics. 2007;50(10):1561-1570.

22. Panagiotopoulou G, Christoulas K, Papanckolaou A, Mandroukas K. Classroom furniture dimensions and anthropometric measures in primary school. Appl Ergon. 2004;35(2):121-128.

23. Castellucci HI, Arezes PM, Viviani CA. Mismatch between classroom furniture and anthropometric measures in Chilean schools. Appl Ergon. 2010;41(4):563-568.

24. Agha SR. School furniture match to students' anthropometry in the Gaza strip. Ergonomics. 2010;53(3):344-354.

25. Gouvali MK, Boudolos K. Match between school furniture dimensions and children's anthropometry. Appl Ergon. 2006;37(6):765-773.

26. Milanese S, Grimmer K. School furniture and their use in population: an anthropometric perspective. Ergonomics. 2004;47(4):416-426.
Advances in Medical Education and Practice

\section{Publish your work in this journal}

Advances in Medical Education and Practice is an international, peerreviewed, open access journal that aims to present and publish research on Medical Education covering medical, dental, nursing and allied health care professional education. The journal covers undergraduate education, postgraduate training and continuing medical education

\section{Dovepress}

including emerging trends and innovative models linking education, research, and health care services. The manuscript management system is completely online and includes a very quick and fair peer-review system. Visit http://www.dovepress.com/testimonials.php to read real quotes from published authors. 